\title{
Design and Build Models of Banana Stem as Material Substitution for Sustainable Manufacturing
}

\author{
Reda Rizal ${ }^{1 *}$, Sargi Br Ginting ${ }^{2}$ \\ ${ }^{1}$ Department of Industrial Engineering, Faculty of Engineering, Universitas Pembangunan Nasional Veteran Jakarta, Indonesia \\ ${ }^{2}$ Department of Naval Architecture Engineering, Faculty of Engineering, Universitas Pembangunan Nasional Veteran Jakarta, \\ Indonesia
}

\begin{abstract}
This research was motivated by the existence of environmental pollution problems caused by manufacturing activities that use styrene plastic materials as part of the packaging for electronic products. To solve these problems, innovative uses of environmentally-friendly materials from natural resources are necessary. The substitution of natural materials for the synthetic materials used in manufacturing is vitally important in the effort to eliminate the negative effects of environmental pollution. The use of trial-and-error methods to create and test replacement materials derived from renewable natural resources will allow sustainable manufacturing development. In this study, we assessed the feasibility of replacing styrene plastic materials, which commonly are used in the packaging of manufactured goods, with waste materials from banana stems so that the packaging of manufactured goods can be an environmentally-friendly product. The resulting banana stem of new and renewable material substitution for sustainable manufacturing, namely the $\mathrm{M}_{4}+\mathrm{T}+\mathrm{P}_{3}+\mathrm{A}+\mathrm{t}_{6}$ model. Micro-biological banana stem material is broken down easily in the soil, so this material does not disturb the environment, while styrene materials do not break down in the soil. The implication of this research is the packaging of manufactured products can be sustainable.
\end{abstract}

Keyword: Environmental pollution, Sustainable manufacturing, Replacing styrene plastic

\section{Introduction}

When consumers buy electronic goods, such as televisions, refrigerators, washing machines, rice cookers, irons, air conditioners, and other household appliances, styrene is almost always used as one of the packaging materials. The physical and chemical properties of styrene are such that it is not degraded easily by the microorganisms in the soil, so its disposal has serious environmental implications due to its adverse effects on the soil, water, and air that can result in adverse effects on human health [1,2]. Currently, the international community has rejected products containing styrene, even though it only functions as a buffer in product packaging [3, 4]. The global community has rejected the presence of products that contain styrene because people are now aware that styrene is produced from non-renewable petroleum products and that its disposal can damage the environment. The advantages of the physical properties of polystyrene plastic in various household product packaging are; Styrene plastic material can increase storage duration, can withstand heat and the price is relatively cheap, so many food manufacturers make it as food packaging $[5,6]$. This study considers a long-term perspective to build a sustainable manufacturing operational system, so that manufactures produce using renewable raw materials, not Styrofoam plastic and are environmentally friendly that are acceptable to global consumers, and products do not pollute the environment when disposed of as waste. The research objective in the medium term is to encourage businesses to carry out their responsibilities to ensure that their use of natural resources is done responsible. The short-term goal of this research is to design a model of Styrofoam plastic replacement material with renewable materials in the form of banana stem waste material to be able to develop sustainable manufacturing. The results of this study encourage sustainability into products and production processes related to environmental, economic and social aspects, forcing manufacturing companies to produce clean products and durable products $[6,7]$. Sustainable manufacturing activities have received great attention from the global community and are an effective solution to support sustainable development $[5,8]$. The three main components of this new perspective are the environment, matter, and energy. The plastic materials that used extensively every day by people all over the world contain various formulations that are derived from oligomeric, monomer, and polymer residues [6]. Polystyrene, which currently is used extensively in every community, including its use in food containers,

\footnotetext{
*Corresponding author : reda.rizal@upnvj.ac.id
} 
contains 30 toxic chemical compounds. Benzaldehyde, styrene, ethylbenzene, and tetradecane are used in manufacturing polystyrene-based products. The release of these toxic compounds into the environment is highly temperature dependent, so it is advisable to regulate the use of styrene in hot products to reduce human exposure to these compounds. Regulation of the use of styrene plastic on food wrappers which can cause side effects in the form of; skin irritation, eye irritation, upper respiratory tract irritation, and adverse gastrointestinal effects Consumer health [9]. If the product packaging made from Polystyrene is used as a hot food wrapper, then the polystyrene will release some harmful chemicals; These include benzaldehyde, pentadecane, tetradecane, ethylbenzene, cumene, isocumene, acetophenone and styrene. Thus, appropriate waste recycling methods must be identified and used to prevent, or at least minimize, people's exposures to Polystyrene and its waste products, some of which could be developed into different useful products, such as gasoline, toluene, and chloroform [10]. It is generally known that the advantages of styrene plastic material for packaging manufactured products include physical strength, modulus of elasticity and density that can be adjusted in the production process. The advantage of this material is that it can be adapted to provide the physical properties required by the manufacturing system, and it can be produced in large quantities and at relatively low cost. However, the use of styrene plastic for various community and industrial purposes can have a polluting impact on the environment $[1,11]$. Judging from the factory that is producing styrene plastic packaging products, it is very logical to find a low cost and easiest process to manage the styrene plastic production system, but it will be difficult to find environmental management if the polystyrene waste disposed of by the community is scattered in many places. It was found that polystyrene foam is soluble in a multitude of solvents, including benzene, toluene, etc. The results of experiments conducted by experts showed that the most appropriate solvents to be used in the green process to produce essential oil constituents were pcymene, terpinene, and phellandrene. $[2,6]$.

\section{Literature review}

The United Nations has disseminated the concept of sustainable development to all societies and industries, the world commission for the environment and development has also launched a theory of our common future that defines the concept of sustainable development. The orientation of the development of technology, and institutional changes are made consistently according to present and future needs. The main idea behind this concept which was introduced at the world summit on sustainable development in Johannesburg, involves determining how to achieve development and growth without excessive use of limited natural resources [2]. The framework of the concept of sustainable development consists of three dimensions, namely the economic, environmental and socio-society dimensions. The introduction of new dimensions has also been added recently, namely the dimensions of technology and education in order to accelerate the realization of the ideals of sustainable development. In considering these different dimensions, there are needs for development supported by economic growth that protects the environment and for a stability of relationship between human activity and the natural environment. In this context, a successful company is defined as a company that maintains its financial growth, produces profits, and meets the environmental and social goals. However, this is not always successful in reality. During the last few decades, several alternative conceptions have been developed for different purposes including research related to sustainable development theory. Research on the evolution of sustainable development has also been carried out, resulting in various concepts to describe sustainable development being developed towards "green minorities" and "green evolution" in the 1980s, "ethical consumer behaviour" in the early 1990s, which subsequently have led to global policies $[2,13]$. The increasing concern of the global community about the negative impact of various manufacturing activities on the environment has prompted researchers to start conducting studies related to manufacturing sustainability. Empirical research has proven that sustainable manufacturing can be used as an alternative comprehensive strategy to minimize the negative impact of manufacturing activities on the environment [14]. The relationship between policy and regulation and availability of resources and companies' performances is not affected significantly by size of the companies. The results of research by experts in Malaysia showed that better environmental performance was related directly with the size of the manufacturing companies, both in terms of their use of natural resources and their impacts on environmental pollution [15]. Styrene is widely produced by manufacturers as a packaging material and household furniture material, but this styrene waste material has a negative impact on the environment and disturbs living things [4, 16]. The solution at the factory is to reuse styrene as an effective product, for example, styrene plastic waste can be reused to improve the performance of hot mix asphalt. In an effort to overcome environmental pollution caused by its manufacturing activities, polystyrene waste is used for building roofs [17]. Similarly, Ede et al. states that waste styrene can be used as a building support material. Several innovative construction materials and technologies have been introduced to support unique modular designs, reduce labor, and save time and costs. The introduction of plastic materials that are considered advanced, and in particular Polystyrene building technology has been developed in the world of construction industry. Innovations carried out by the industry that produces styrene plastic find brilliant initiatives that are very useful and help in reducing construction costs, but this construction waste will still harm the environment when the construction goods become waste [18]. Styrene industrial waste has been applied in an effort to produce lightweight concrete that 
has good resistance to water, but this concrete waste will still endanger the environment when the concrete becomes waste $[1,9,19]$. Likewise, electronic waste is increasing rapidly, including various types of plastic, such as polystyrene, because it can be used as packaging for electronic goods, but this electronic waste will still endanger the environment when the electronic goods are not used as waste $[1,9,18,20]$. Plastic waste that is not environmentally friendly has a significant effect because of the negative impact of chemical and oil degradation on the soil environment. Concerns about the sustainability of products and production processes have forced manufacturers to shift from making decisions based solely on economics to envisioning more holistic goals encompassing economic, environmental and socio-social perspectives [21]. Extensive studies have focused on creating opportunities to minimize waste, eliminating the negative impact of manufacturing activities on the environment and society. Traditionally, sustainable manufacturing practices are seen as a burden by companies because they tend to reduce the efficiency of companies and reduce their opportunities for profit. On the other hand, successful implementation of sustainable manufacturing initiatives will benefit the company by reducing waste management operational costs and increasing customer satisfaction [22]. In the context of green manufacturing, creating sustainable value requires production systems, products, processes, and innovations to allow closed cycle material flow within the factory area, so that none of the materials becomes waste because all materials are used cyclically in the manufacturing area [23]. It can understood the complicated interactions that occur with the natural environment in a socio-technical system to create situations so that harmonious and sustainable values emerge. Manufacturing that produces innovatively and sustainably can be a driver of sustainable economic growth, because in addition to encouraging economic growth, it will also encourage increased social welfare, as well as environmentally conscious practices. Product innovation, process, input system, and product output are needed in every material life cycle to achieve manufacturing sustainability. Several experts present a system model of the green manufacturing paradigm, and this model identifies various planning activities to change less environmentally friendly manufacturing into more environmentally friendly manufacturing. [18, 24]. The proposed model is a comprehensive qualitative approach to design quantitatively and thoroughly improve the value of green manufacturing systems to evaluate the new paradigm. Polystyrene is a synthetic material that is very stable at temperatures below $0^{\circ} \mathrm{C}$. The use of polystyrene is very extensive in the activities of manufacturing industries that produce consumer goods, such as food packaging materials, electronic packaging, automotive spare parts, and daily needs [9]. Some people may not realize that the disposal of Polystyrene waste into the environment will disrupt the quality of the environment. Due to its high level of stability at low temperatures, it is certain that styrene has good stability in the soil, is difficult for micro-organisms in the soil to decompose, and is disruptive of the natural life in the soil [12].

\section{Methods}

To support environmental friendly manufacturing development research activities, appropriate research methods are needed, namely using the experimental method (trial and error) [8]. This systems approach considers three manufacturing sub-systems namely technology, energy and materials that can be created to improve the performance of the manufacturing environment. The manufacturing performance studied in the production raw material material sub-system will be focused on examining the feasibility of banana stem waste as a substitute for Styrofoam plastic material in electronic product packaging. The manufacturing performance of this electronic product reflects the level of manufacturing sustainability through efforts to minimize sources of environmental impact from manufacturing activities. In this trial and error method, if the design of the material, energy and technology ideas produced is not in accordance with the plan, then a redesign of the raw materials used in the production process is immediately carried out. [24].

Table 1: Banana stem model experiment treatment

\begin{tabular}{|c|c|c|c|c|}
\hline No. & \multicolumn{4}{|c|}{ Combination of experimental treatment ${ }^{*}$} \\
\hline 1 & $\begin{array}{c}\mathrm{M}_{3}+\mathrm{T}+ \\
\mathrm{P}_{1}+\mathrm{A}+\mathrm{t}_{1}\end{array}$ & $\begin{array}{c}\mathrm{M}_{3}+\mathrm{T}+\mathrm{P}_{3} \\
+\mathrm{A}+\mathrm{t}_{1}\end{array}$ & $\begin{array}{c}\mathrm{M}_{4}+\mathrm{T}+\mathrm{P}_{1} \\
+\mathrm{A}+\mathrm{t}_{1}\end{array}$ & $\begin{array}{c}\mathrm{M}_{3}+\mathrm{T}+\mathrm{P}_{2} \\
+\mathrm{A}+\mathrm{t}_{1}\end{array}$ \\
\hline 2 & $\begin{array}{c}\mathrm{M}_{3}+\mathrm{T}+ \\
\mathrm{P}_{1}+\mathrm{A}+\mathrm{t}_{2}\end{array}$ & $\begin{array}{c}\mathrm{M}_{3}+\mathrm{T}+\mathrm{P}_{3} \\
+\mathrm{A}+\mathrm{t}_{2}\end{array}$ & $\begin{array}{c}\mathrm{M}_{4}+\mathrm{T}+\mathrm{P}_{1} \\
+\mathrm{A}+\mathrm{t}_{2}\end{array}$ & $\begin{array}{c}\mathrm{M}_{3}+\mathrm{T}+\mathrm{P}_{2} \\
+\mathrm{A}+\mathrm{t}_{2}\end{array}$ \\
\hline 3 & $\begin{array}{c}\mathrm{M}_{3}+\mathrm{T}+ \\
\mathrm{P}_{1}+\mathrm{A}+\mathrm{t}_{3}\end{array}$ & $\begin{array}{c}\mathrm{M}_{3}+\mathrm{T}+\mathrm{P}_{3} \\
+\mathrm{A}+\mathrm{t}_{3}\end{array}$ & $\begin{array}{c}\mathrm{M}_{4}+\mathrm{T}+\mathrm{P}_{1} \\
+\mathrm{A}+\mathrm{t}_{3}\end{array}$ & $\begin{array}{c}\mathrm{M}_{3}+\mathrm{T}+\mathrm{P}_{2} \\
+\mathrm{A}+\mathrm{t}_{3}\end{array}$ \\
\hline 4 & $\begin{array}{c}\mathrm{M}_{3}+\mathrm{T}+ \\
\mathrm{P}_{1}+\mathrm{A}+\mathrm{t}_{4} \\
\end{array}$ & $\begin{array}{c}\mathrm{M}_{3}+\mathrm{T}+\mathrm{P}_{3} \\
+\mathrm{A}+\mathrm{t}_{4}\end{array}$ & $\begin{array}{c}\mathrm{M}_{4}+\mathrm{T}+\mathrm{P}_{1} \\
+\mathrm{A}+\mathrm{t}_{4}\end{array}$ & $\begin{array}{c}\mathrm{M}_{3}+\mathrm{T}+\mathrm{P}_{2} \\
+\mathrm{A}+\mathrm{t}_{4}\end{array}$ \\
\hline 5 & $\begin{array}{c}\mathrm{M}_{3}+\mathrm{T}+ \\
\mathrm{P}_{1}+\mathrm{A}+\mathrm{t}_{5}\end{array}$ & $\begin{array}{c}\mathrm{M}_{3}+\mathrm{T}+\mathrm{P}_{3} \\
+\mathrm{A}+\mathrm{t}_{5}\end{array}$ & $\begin{array}{c}\mathrm{M}_{4}+\mathrm{T}+\mathrm{P}_{1} \\
+\mathrm{A}+\mathrm{t}_{5}\end{array}$ & $\begin{array}{c}\mathrm{M}_{3}+\mathrm{T}+\mathrm{P}_{2} \\
+\mathrm{A}+\mathrm{t}_{5}\end{array}$ \\
\hline 6 & $\begin{array}{c}\mathrm{M}_{3}+\mathrm{T}+ \\
\mathrm{P}_{1}+\mathrm{A}+\mathrm{t}_{6} \\
\end{array}$ & $\begin{array}{c}\mathrm{M}_{3}+\mathrm{T}+\mathrm{P}_{3} \\
+\mathrm{A}+\mathrm{t}_{6}\end{array}$ & $\begin{array}{c}\mathrm{M}_{4}+\mathrm{T}+\mathrm{P}_{1} \\
+\mathrm{A}+\mathrm{t}_{6}\end{array}$ & $\begin{array}{c}\mathrm{M}_{3}+\mathrm{T}+\mathrm{P}_{2} \\
+\mathrm{A}+\mathrm{t}_{6}\end{array}$ \\
\hline 7 & $\begin{array}{c}\mathrm{M}_{2}+\mathrm{T}+ \\
\mathrm{P}_{2}+\mathrm{A}+\mathrm{t}_{2} \\
\end{array}$ & $\begin{array}{c}\mathrm{M}_{4}+\mathrm{T}+\mathrm{P}_{2} \\
+\mathrm{A}+\mathrm{t}_{2}\end{array}$ & $\begin{array}{c}\mathrm{M}_{4}+\mathrm{T}+\mathrm{P}_{3} \\
+\mathrm{A}+\mathrm{t}_{2}\end{array}$ & $\begin{array}{c}\mathrm{M}_{2}+\mathrm{T}+\mathrm{P}_{3} \\
+\mathrm{A}+\mathrm{t}_{2}\end{array}$ \\
\hline 8 & $\begin{array}{c}\mathrm{M}_{2}+\mathrm{T}+ \\
\mathrm{P}_{2}+\mathrm{A}+\mathrm{t}_{4}\end{array}$ & $\begin{array}{c}\mathrm{M}_{4}+\mathrm{T}+\mathrm{P}_{2} \\
+\mathrm{A}+\mathrm{t}_{4}\end{array}$ & $\begin{array}{c}\mathrm{M}_{4}+\mathrm{T}+\mathrm{P}_{3} \\
+\mathrm{A}+\mathrm{t}_{4}\end{array}$ & $\begin{array}{c}\mathrm{M}_{2}+\mathrm{T}+\mathrm{P}_{3} \\
+\mathrm{A}+\mathrm{t}_{4}\end{array}$ \\
\hline 9 & $\begin{array}{c}\mathrm{M}_{2}+\mathrm{T}+ \\
\mathrm{P}_{2}+\mathrm{A}+\mathrm{t}_{6} \\
\end{array}$ & $\begin{array}{c}\mathrm{M}_{4}+\mathrm{T}+\mathrm{P}_{2} \\
+\mathrm{A}+\mathrm{t}_{6}\end{array}$ & $\begin{array}{c}\mathrm{M}_{4}+\mathrm{T}+\mathrm{P}_{3} \\
+\mathrm{A}+\mathrm{t}_{6} \\
\end{array}$ & $\begin{array}{c}\mathrm{M}_{2}+\mathrm{T}+\mathrm{P}_{3} \\
+\mathrm{A}+\mathrm{t}_{6}\end{array}$ \\
\hline 10 & $\begin{array}{c}\mathrm{M}_{1}+\mathrm{T}+ \\
\mathrm{P}_{1}+\mathrm{A}+\mathrm{t}_{1} \\
\end{array}$ & $\begin{array}{c}\mathrm{M}_{1}+\mathrm{T}+\mathrm{P}_{3} \\
+\mathrm{A}+\mathrm{t}_{1}\end{array}$ & $\begin{array}{c}\mathrm{M}_{2}+\mathrm{T}+\mathrm{P}_{1} \\
+\mathrm{A}+\mathrm{t}_{1}\end{array}$ & $\begin{array}{c}\mathrm{M}_{1}+\mathrm{T}+\mathrm{P}_{2} \\
+\mathrm{A}+\mathrm{t}_{1} \\
\end{array}$ \\
\hline 11 & $\begin{array}{c}\mathrm{M}_{1}+\mathrm{T}+ \\
\mathrm{P}_{1}+\mathrm{A}+\mathrm{t}_{2}\end{array}$ & $\begin{array}{c}\mathrm{M}_{1}+\mathrm{T}+\mathrm{P}_{3} \\
+\mathrm{A}+\mathrm{t}_{2}\end{array}$ & $\begin{array}{c}\mathrm{M}_{2}+\mathrm{T}+\mathrm{P}_{1} \\
+\mathrm{A}+\mathrm{t}_{2}\end{array}$ & $\begin{array}{c}\mathrm{M}_{1}+\mathrm{T}+\mathrm{P}_{2} \\
+\mathrm{A}+\mathrm{t}_{2}\end{array}$ \\
\hline 12 & $\begin{array}{c}\mathrm{M}_{1}+\mathrm{T}+ \\
\mathrm{P}_{1}+\mathrm{A}+\mathrm{t}_{3}\end{array}$ & $\begin{array}{c}\mathrm{M}_{1}+\mathrm{T}+\mathrm{P}_{3} \\
+\mathrm{A}+\mathrm{t}_{3}\end{array}$ & $\begin{array}{c}\mathrm{M}_{2}+\mathrm{T}+\mathrm{P}_{1} \\
+\mathrm{A}+\mathrm{t}_{3}\end{array}$ & $\begin{array}{c}\mathrm{M}_{1}+\mathrm{T}+\mathrm{P}_{2} \\
+\mathrm{A}+\mathrm{t}_{3}\end{array}$ \\
\hline 13 & $\begin{array}{c}\mathrm{M}_{1}+\mathrm{T}+ \\
\mathrm{P}_{1}+\mathrm{A}+\mathrm{t}_{4} \\
\end{array}$ & $\begin{array}{c}\mathrm{M}_{1}+\mathrm{T}+\mathrm{P}_{3} \\
+\mathrm{A}+\mathrm{t}_{4}\end{array}$ & $\begin{array}{c}\mathrm{M}_{2}+\mathrm{T}+\mathrm{P}_{1} \\
+\mathrm{A}+\mathrm{t}_{4}\end{array}$ & $\begin{array}{c}\mathrm{M}_{1}+\mathrm{T}+\mathrm{P}_{2} \\
+\mathrm{A}+\mathrm{t}_{4}\end{array}$ \\
\hline 14 & $\begin{array}{c}\mathrm{M}_{1}+\mathrm{T}+ \\
\mathrm{P}_{1}+\mathrm{A}+\mathrm{t}_{5} \\
\end{array}$ & $\begin{array}{c}\mathrm{M}_{1}+\mathrm{T}+\mathrm{P}_{3} \\
+\mathrm{A}+\mathrm{t}_{5}\end{array}$ & $\begin{array}{c}\mathrm{M}_{2}+\mathrm{T}+\mathrm{P}_{1} \\
+\mathrm{A}+\mathrm{t}_{5}\end{array}$ & $\begin{array}{c}\mathrm{M}_{1}+\mathrm{T}+\mathrm{P}_{2} \\
+\mathrm{A}+\mathrm{t}_{5}\end{array}$ \\
\hline 15 & $\begin{array}{c}\mathrm{M}_{1}+\mathrm{T}+ \\
\mathrm{P}_{1}+\mathrm{A}+\mathrm{t}_{6} \\
\end{array}$ & $\begin{array}{c}\mathrm{M}_{1}+\mathrm{T}+\mathrm{P}_{3} \\
+\mathrm{A}+\mathrm{t}_{6} \\
\end{array}$ & $\begin{array}{c}\mathrm{M}_{2}+\mathrm{T}+\mathrm{P}_{1} \\
+\mathrm{A}+\mathrm{t}_{6}\end{array}$ & $\begin{array}{c}\mathrm{M}_{1}+\mathrm{T}+\mathrm{P}_{2} \\
+\mathrm{A}+\mathrm{t}_{6} \\
\end{array}$ \\
\hline 16 & $\begin{array}{c}\mathrm{M}_{2}+\mathrm{T}+ \\
\mathrm{P}_{2}+\mathrm{A}+\mathrm{t}_{1} \\
\end{array}$ & $\begin{array}{c}\mathrm{M}_{4}+\mathrm{T}+\mathrm{P}_{2} \\
+\mathrm{A}+\mathrm{t}_{1} \\
\end{array}$ & $\begin{array}{c}\mathrm{M}_{4}+\mathrm{T}+\mathrm{P}_{3} \\
+\mathrm{A}+\mathrm{t}_{1} \\
\end{array}$ & $\begin{array}{c}\mathrm{M}_{2}+\mathrm{T}+\mathrm{P}_{3} \\
+\mathrm{A}+\mathrm{t}_{1} \\
\end{array}$ \\
\hline 17 & $\begin{array}{c}\mathrm{M}_{2}+\mathrm{T}+ \\
\mathrm{P}_{2}+\mathrm{A}+\mathrm{t}_{3}\end{array}$ & $\begin{array}{c}\mathrm{M}_{4}+\mathrm{T}+\mathrm{P}_{2} \\
+\mathrm{A}+\mathrm{t}_{3}\end{array}$ & $\begin{array}{c}\mathrm{M}_{4}+\mathrm{T}+\mathrm{P}_{3} \\
+\mathrm{A}+\mathrm{t}_{3}\end{array}$ & $\begin{array}{c}\mathrm{M}_{2}+\mathrm{T}+\mathrm{P}_{3} \\
+\mathrm{A}+\mathrm{t}_{3}\end{array}$ \\
\hline 18 & $\begin{array}{c}\mathrm{M}_{2}+\mathrm{T}+ \\
\mathrm{P}_{2}+\mathrm{A}+\mathrm{t}_{5}\end{array}$ & $\begin{array}{c}\mathrm{M}_{4}+\mathrm{T}+\mathrm{P}_{2} \\
+\mathrm{A}+\mathrm{t}_{5}\end{array}$ & $\begin{array}{c}\mathrm{M}_{4}+\mathrm{T}+\mathrm{P}_{3} \\
+\mathrm{A}+\mathrm{t}_{5}\end{array}$ & $\begin{array}{c}\mathrm{M}_{2}+\mathrm{T}+\mathrm{P}_{3} \\
+\mathrm{A}+\mathrm{t}_{5}\end{array}$ \\
\hline
\end{tabular}

${ }^{a}$ Material (M): 4 Variation $\left(\mathrm{M}_{1}\right.$ dimension $4 \times 4 \mathrm{~cm}, \mathrm{M}_{2}$ dimension $3 \times 3 \mathrm{~cm}, \mathrm{M}_{3}$ dimension $2 \times 2 \mathrm{~cm}, \mathrm{M}_{4}$ dimension 1 $\mathrm{x} 1 \mathrm{~cm})$; pressure $(\mathrm{P}): 3$ Variation $\left(\mathrm{P} 1=15 \mathrm{~kg} / \mathrm{cm}^{2}, \mathrm{P}_{2}=10\right.$ 
$\left.\mathrm{kg} / \mathrm{cm}^{2}, \mathrm{P}_{3}=5 \mathrm{~kg} / \mathrm{cm}^{2}\right)$; time $(\mathrm{t}): 6$ Variation $\left(\mathrm{t}_{1}=30^{\prime}, \mathrm{t}_{2}=\right.$ $\left.60^{\prime}, \mathrm{t}_{3}=90^{\prime}, \mathrm{t}_{4}=120^{\prime}, \mathrm{t}_{5}=150^{\prime}, \mathrm{t}_{6}=180^{\prime}\right)$; temperature $(\mathrm{T})$ : $1 \times 250^{\circ} \mathrm{C}$; adhesive (A): $1 \times 15$ gram
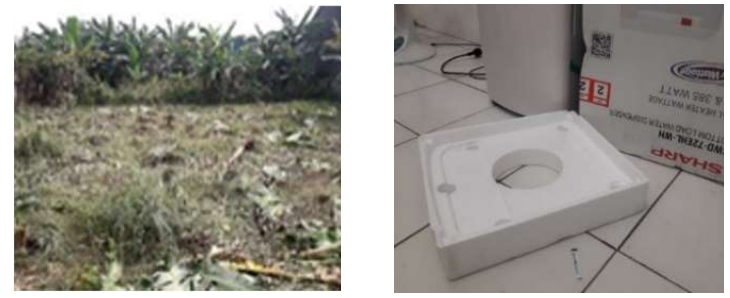

Fig 1. Waste of banana tree.

Fig 2. Styrene of manufactured product packaging.

Waste of banana stems taken from plantations after the bananas are harvested, and the banana stem material (Fig. 1) is used as a substitute for styrene (Fig. 2), which generally is used as a wedge in the packaging of electronic goods and other manufactured goods.

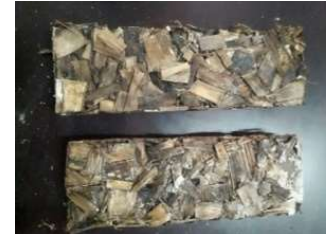

Figure 3. Banana stem material model as research result for substitution material.

Fig. 3 shows the results of experiments on substituting banana stem material (Fig. 4) for styrene for use as the wedge in packaging a water dispenser. By using a trial method on a laboratory scale, it is expected that the results of the study will produce a banana stem material that can replace the function of styrene in the packaging of manufactured products. Thus, subsequently, manufacturing production operations can produce environmentally friendly products, and the use of non-renewable natural resources for the manufacture of styrene can be reduced or avoided.

\section{Result and discussion}

\subsection{Manufacturing system}

The material cycle and energy flow in a manufacturing system can be analogous to the interaction of the manufacturing system with the surrounding natural environment which is known as manufacturing metabolism [9, 25]. Manufacturing metabolic processes are similar to metabolism in the human body in that there are raw materials, processes, products, and entropy. The concept of manufacturing metabolism examines the problem of integrating physical processes that convert raw materials, energy, and labor into final products and wastes $[13,26]$. The labor output factor in the production process and product output for consumers will act as a social component that can be used as a controlling factor for the stability of the production process in sustainable manufacturing activities. The word metabolism refers to the internal processes of living organisms that are necessary for life and maintenance and life [24, 27]. There are many manufacturers that use styrene as the main raw material and with other auxiliary raw materials in their production system. The system consists of input subsystem, process subsystem, output subsystem, and waste subsystem. [17]. In manufacturing, for example, the manufacture of electronic rice cooker technology, the main raw materials as input sub-systems are iron, zinc, plastic, and heating capacitors. [26]. When styrene is used for packaging, other auxiliary materials are paper, cardboard, and other plastic materials. Regarding the sustainability of the manufacturing system, the US Environmental Protection Agency has banned the use of styrene because it is an environmental pollutant [27].

\subsection{Material substitution}

It was found that many manufacturers of electronic equipment still use non-renewable materials, such as styrene, as raw materials to support the packaging of electronic goods. The existence of styrene material in the packaging of electronic goods, among others, functions as a cushion in the packaging of television sets, rice cookers, ovens, dispensers, water pumps, and other electronic products $[9,25]$. The material used to replace styrene in this study was banana stem, which can be engineered to serve as a substitute for styrene, which electronics manufacturers usually use, as mentioned above. In order for every manufactured product to meet the demands of the global market that requires environmentally friendly products, the current manufacturing process must immediately be changed to a sustainable manufacturing process [24]. Researchers from manufacturing companies have successfully integrated environmental management concepts into manufacturing strategy models. First of all, they prove that environmental factors are highly relevant to the strategic perspective of the criteria of sequence, qualification, and process choice considerations. Later, work agreements must be offered that are built on the development and integration of manufacturing strategies into a unified strategy that integrates environmental issues. Thus, important strategies for manufacturing companies will include computerintegrated manufacturing, adding high-value production, saving resources, preserving the production environment, and solving problems according to social preferences. [13, 26].

Table 2 Banana stem model test result matrix

\begin{tabular}{cccc}
\hline $\mathrm{M}$ & $\mathrm{T}+\mathrm{P}_{1}+\mathrm{A}+\mathrm{t}_{1}$ & $\mathrm{~T}+\mathrm{P}_{2}+\mathrm{A}+\mathrm{t}_{1}$ & $\mathrm{~T}+\mathrm{P}_{3}+\mathrm{A}+\mathrm{t}_{1}$ \\
\hline $\mathrm{M}_{1}$ & 1 & 2 & 3 \\
\hline $\mathrm{M}_{2}$ & 10 & 11 & 12 \\
\hline $\mathrm{M}_{3}$ & 19 & 20 & 21 \\
\hline
\end{tabular}




\begin{tabular}{cccc}
\hline $\mathrm{M}_{4}$ & 28 & 29 & 30 \\
\hline & $\mathrm{T}+\mathrm{P}_{1}+\mathrm{A}+\mathrm{t}_{2}$ & $\mathrm{~T}+\mathrm{P}_{2}+\mathrm{A}+\mathrm{t}_{2}$ & $\mathrm{~T}+\mathrm{P}_{3}+\mathrm{A}+\mathrm{t}_{2}$ \\
\hline $\mathrm{M}_{1}$ & 4 & 5 & 6 \\
\hline $\mathrm{M}_{2}$ & 13 & 14 & 15 \\
\hline $\mathrm{M}_{3}$ & 22 & 23 & 24 \\
\hline $\mathrm{M}_{4}$ & 31 & 32 & 33 \\
\hline & $\mathrm{T}+\mathrm{P}_{1}+\mathrm{A}+\mathrm{t}_{3}$ & $\mathrm{~T}+\mathrm{P}_{2}+\mathrm{A}+\mathrm{t}_{3}$ & $\mathrm{~T}+\mathrm{P}_{3}+\mathrm{A}+\mathrm{t}_{3}$ \\
\hline $\mathrm{M}_{1}$ & 4 & 5 & 6 \\
\hline $\mathrm{M}_{2}$ & 13 & 14 & 15 \\
\hline $\mathrm{M}_{3}$ & 22 & 23 & 24 \\
\hline $\mathrm{M}_{4}$ & 31 & 32 & 33 \\
\hline & $\mathrm{T}+\mathrm{P}_{1}+\mathrm{A}+\mathrm{t}_{4}$ & $\mathrm{~T}+\mathrm{P}_{2}+\mathrm{A}+\mathrm{t}_{4}$ & $\mathrm{~T}+\mathrm{P}_{3}+\mathrm{A}+\mathrm{t}_{4}$ \\
\hline $\mathrm{M}_{1}$ & 37 & 38 & 39 \\
\hline $\mathrm{M}_{2}$ & 46 & 47 & 48 \\
\hline $\mathrm{M}_{3}$ & 55 & 56 & 57 \\
\hline $\mathrm{M}_{4}$ & 64 & 65 & 66 \\
\hline & $\mathrm{T}+\mathrm{P}_{1}+\mathrm{A}+\mathrm{t}_{5}$ & $\mathrm{~T}+\mathrm{P}_{2}+\mathrm{A}+\mathrm{t}_{5}$ & $\mathrm{~T}+\mathrm{P}_{3}+\mathrm{A}+\mathrm{t}_{5}$ \\
\hline $\mathrm{M}_{1}$ & 40 & 41 & 42 \\
\hline $\mathrm{M}_{2}$ & 49 & 50 & 51 \\
\hline $\mathrm{M}_{3}$ & 58 & 59 & 60 \\
\hline $\mathrm{M}_{4}$ & 67 & 68 & 69 \\
\hline & $\mathrm{T}+\mathrm{P}_{1}+\mathrm{A}+\mathrm{t}_{6}$ & $\mathrm{~T}+\mathrm{P}_{2}+\mathrm{A}+\mathrm{t}_{6}$ & $\mathrm{~T}+\mathrm{P}_{3}+\mathrm{A}+\mathrm{t}_{6}$ \\
\hline $\mathrm{M}_{1}$ & 43 & 44 & 45 \\
\hline $\mathrm{M}_{2}$ & 52 & 53 & 54 \\
\hline $\mathrm{M}_{3}$ & 61 & 62 & 63 \\
\hline $\mathrm{M}_{4}$ & 70 & 71 & 72 \\
\hline & & &
\end{tabular}

Material from experimental design $\mathrm{M}_{4}+\mathrm{T}+\mathrm{P}_{3}+\mathrm{A}$ $+t_{6}$ turned out to be a model that has physical characteristics that are almost the same as those of styrene. These characteristics of the physical properties include the material's level of hardness, elasticity, and weight. Sustainability of manufacturing utilizing this model material can be obtained from the nature of banana stem material, which is decomposed easily in soil when it becomes waste, so that it is safe for the environment and becomes an environmentally-friendly material.

\subsection{Renewable material}

Renewable materials are materials that can be renewed naturally, such as vegetation and animals. Vegetation materials used as raw materials for production in manufacturing, for example, are cotton as raw material for yarn production, yarn as raw material for making cloth, cloth as raw material for the production of clothes, shoes, bags, jackets [25]. Materials derived from animals such as leather can be used as raw materials for production; shoes, footwear, bags, jackets, and belts. Cotton material can grow and develop naturally in plantation systems for 4 to 6 months, and cowhide material can grow and develop in livestock systems for 3 to 4 years. The two examples of cotton and cowhide materials can be used as main raw materials and auxiliary raw materials in manufacturing production systems [26]. The type of vegetation used as raw material in this research is banana stem waste. Banana trees as a renewable natural resource generally grow and are ready to harvest for approximately 6 months. In the banana plantation system, when harvesting bananas that are 6 months old, banana stems are discarded as garbage. Banana stem waste is widely used by rural communities to be used as raw materials for making handicraft products, raw materials for making paper, fuel, enzymes, animal feed ingredients, ropes, and plant media [25]. In this study, banana stem waste was cut into small pieces, dried and used as raw material for producing electronic packaging products produced by electronic manufacturers. Natural resources in the form of banana stem waste can be used as a substitute for synthetic materials for packaging electronic goods. Manufacturing activities can be categorized as sustainable manufacturing. Likewise, if the manufacturer is able to increase the useful value of banana stem waste waste to be used as raw material for production, then the manufacturer has contributed to utilizing waste material that has not been utilized by modern manufacturers [24, 25, 26, 29].

\subsection{Sustainable Manufacture}

Theoretical review of different definitions indicated that there were inconsistencies about how sustainable manufacture is addressed in literature. The writers define sustainable manufacture (SM) as a strategy or an approach, the others define it as a paradigm of a system $[2,7]$. The main theme of SM research tends to be the development of environmental indicators or the assessment of the environmental impact of SM. Researchers argue that sustainability is often summarized for environmental improvement, which requires an integrated perspective combines with sustainability issues. In addition, it is clear that there is an absence of a relevant theoretical framework to serve as the SM foundation practices. Some research contexts, including large plants and SMEs, also were observed. Researcher articulated the need for further SM research in the SME context links with the application of SME sustainable manufacturing practices [26]. Most articles defined SM as the creation of products and services. The difference in terms used to define SM indicates a lack of agreement among scholars about the true meaning of the concept SM. Including the definition of SM as a strategy for a global production system that adheres to a closed cycle supply system [28]. The concept of sustainable manufacturing (SM) has become more important because it has been applied to various topics that have been practiced for a long time $[22,26]$. The results of a survey of styrene producers in the production process show that the SM concept has been practiced without a doubt, but there are still many definitions of SM that are poorly understood. Thus, it is hoped that this difference will not hinder the development of the SM concept in practice $[7,27]$. The discussion in this paper proposes the competitive sustainability of new manufacturing by prioritizing and investigating sustainability relationships as they relate to other manufacturing goals and by considering the possibilities of a logical sequence to improve them. This step actually began in 1996, and it has been deemed to be a priority in the development, social preservation, and safety of workplaces, as well as the sustainability of natural resources with dimensions $[25,29,32]$. Recommendations for improvements, 
technological changes, and changes in operational practices as factors that are supported in operating functions even though there are differences in labor and labor in functions related to human resources. The survey results show how the improvement of SM practices in the production system is closely related to environmental aspects, manufacturing stewardship, and competitive products both in terms of cost and production quality. Product stewardship has been practiced, but it does not improve the quality of products significantly. However, both refute and practice positive product supervision with competitive results, including company image, new customer, and company innovation [13, 22, 34]. Based on the results of a survey of several manufacturers that use styrene their production, it was apparent that sustainability has become part of the vision and the strategy of manufacturing businesses, and top management focuses on and puts pressure on the aspects of sustainability. Many manufacturing companies consider that sustainability is not a top priority, because it is not a consumer need. Thus, sustainability is generally not used as the main strategy for manufacturing to improve its performance $[26,27,29,32]$. This shows that incorporating the aspects of sustainability in business strategies does not directly lead to the integration of sustainability into functional strategies. Sustainability activities are not a formal priority, but are carried out to some extent in operations. Sustainability-oriented initiatives can be carried out in parallel with formal manufacturing strategies. Therefore, sustainabilityoriented initiatives are not derived directly from formal manufacturing strategies but can support business sustainability [28, 29, 32]. The management system appeared to hinder the operationalization of sustainability in the manufacturing company that was studied [30, 31, 34].

\section{Conclusion}

The design of experimental research models for the substitution of renewable materials for the development of sustainable manufacturing has been successful with a $95 \%$ performance rate. The model that has physical properties that are close to the properties of styrene is $\mathrm{M}_{4}+\mathrm{T}+\mathrm{P}_{3}+\mathrm{A}+\mathrm{t}_{6}$, and the greater the amount of the material in the experiment, the more likely it is that the research results will be unacceptable. Experimental waste material can be reused as raw material for the next experimental treatment to make different samples. Banana stem waste material easily decomposes in the soil, so this waste material does not damage the environment. Since styrene does not break down in the soil, it is a waste material that can have an adverse effect on the environment. Thus, banana stem waste material can be used as a substitute for styrene because it is more environmentally friendly than styrene, and the priority target for the use of renewable natural resources by manufacturing companies can be achieved sustainably. It is very relevant to integrate sustainable manufacturing operations into the strategy of making alternative materials that are recommended to replace styrene material with banana stem materials as environmentally friendly materials. In particular, this article seeks to expand perspectives concerning the field of sustainable manufacturing strategies and their operationalization by prioritizing the use of renewable natural resources. Material innovation from the results of this research provides an alternative that integrates economic aspects into the social and environmental aspects, making it suitable for use as a business strategy for sustainable manufacturing.

\section{References}

1. Ibrahim, D., Bankole, O. C., Ma'aji, S. A., Ohize, E. J., \& Abdul, B. K. (2013). Assessment of the strength properties of polystyrene material used in building construction in Mbora district of Abuja, Nigeria. International Journal of Engineering Research and Development, 6(12), 80-84.

2. Smith, L., \& Ball, P. (2012). Steps towards sustainable manufacturing through modelling material, energy and waste flows. International Journal of Production Economics, 140(1), 227238.

3. García, M. T., Gracia, I., Duque, G., de Lucas, A., \& Rodríguez, J. F. (2009). Study of the solubility and stability of polystyrene wastes in a dissolution recycling process. Waste management, 29(6), 1814-1818.

4. Aljaibachi, R., \& Callaghan, A. (2018). Impact of polystyrene microplastics on Daphnia magna mortality and reproduction in relation to food availability. PeerJ, 6, e4601.

5. Amirshaghaghi, Z. A. H. R. A., Djomeh, Z. E., \& Oromiehie, A. B. D. U. L. R. A. S. O. U. L. (2011). Studies of migration of styrene monomer from polystyrene packaging into the food simulant. Iranian Journal of Chemical Engineering, 8(4), 43-49.

6. Pajaro-Castro, N., Caballero-Gallardo, K., \& Olivero-Verbel, J. (2014). Identification of volatile organic compounds (VOCs) in plastic products using gas chromatography and mass spectrometry (GC/MS). Revista Ambiente \& Água, 9(4), 610-620.

7. Molamohamadi, Z., \& Ismail, N. (2013). Developing a new scheme for sustainable manufacturing. International Journal of Materials, Mechanics and Manufacturing, 1(1), 1-5.

8. Yuan, C., Zhai, Q., \& Dornfeld, D. (2012). A three-dimensional system approach for environmentally sustainable manufacturing. CIRP annals, 61(1), 39-42.

9. Marten, B., \& Hicks, A. (2018). Expanded Polystyrene Life Cycle Analysis Literature Review: An Analysis for Different Disposal Scenarios. Sustainability: The Journal of Record, 11(1), 29-35. 
10. Osemeahon, S. A., Barminas, J. T., \& Jang, A. L. (2013). Development of Waste Polystyrene as a binder for emulsion paint formulation I: Effect of polystyrene Concentration. The International Journal of Engineering and Science (IJES), 2(8), $30-5 \mathrm{p}$.

11. Rouabah, F., Dadache, D., \& Haddaoui, N. (2012). Thermophysical and mechanical properties of polystyrene: influence of free quenching. ISRN Polymer Science, 2012.

12. García, M. T., Gracia, I., Duque, G., de Lucas, A., \& Rodríguez, J. F. (2009). Study of the solubility and stability of polystyrene wastes in a dissolution recycling process. Waste management, 29(6), 1814-1818.

13. Taghavi, N. (2015). Sustainable Manufacturing Strategy: Identifying Gaps in Theory and Practice (Doctoral dissertation, Chalmers University of Technology).

14. Vigneswaran, C., Pavithra, V., Gayathri, V., \& Mythili, K. (2015). Banana fiber: scope and value added product development. Journal of Textile and Apparel, Technology and Management, 9(2).

15. Roni, M., Jabar, J., Muhamad, M. R., \& Murad, M. (2017). Sustainable manufacturing drivers and firm performance: Moderating effect of firm size. International $J$. of Adv. \& Applied Scien., 4(12), 243-249.

16. Nassar, I. M., Kabel, K. I., \& Ibrahim, I. M. (2012). Evaluation of the effect of waste polystyrene on performance of asphalt binder. ARPN J. of Sci. \& Tech., 2(10), 927-935.

17. Ngugi, H. N., Kaluli, J. W., \& Abiero-Gariy, Z. Use of expanded polystyrene technology and materials recycling for building construction in Kenya. American Journal of Engineering and Technology Management, 2(5), 64-71, (2017).

18. Ede, A. N., Alegiuno, V., \& Awoyera, P. O. (2014). Use of advanced plastic materials in Nigeria: Performance assessment of expanded polystyrene building technology system. Use of Advanced Plastic Materials in Nigeria: Performance Assessment of Expanded Polystyrene Building Technology System, 3(4), 301-308.

19. Ngugi, H. N., Kaluli, J. W., \& Abiero-Gariy, Z. (2017). Use of expanded polystyrene technology and materials recycling for building construction in Kenya. American Journal of Engineering and Technology Management, 2(5), 64-71.

20. Sekhar, V. C., Nampoothiri, K. M., Mohan, A. J., Nair, N. R., Bhaskar, T., \& Pandey, A. (2016). Microbial degradation of high impact polystyrene (HIPS), an e-plastic with decabromodiphenyl oxide and antimony trioxide. Journal of hazardous materials, 318, 347-354.

21. Ocampo, L., \& Clark, E. (2015). A sustainable manufacturing strategy decision framework in the context of multi-criteria decision-making. Jordan Journal of Mechanical \& Industrial Engineering, $9(3)$.
22. Nordin, N., Ashari, H., \& Rajemi, M. F. (2014). A Case Study of Sustainable Manufacturing Practices'. Journal of Advanced Management Science Vol, 2(1), 12-16.

23. Jawahir, I. S., Badurdeen, F., \& Rouch, K. E. (2015). Innovation in sustainable manufacturing education. Universitätsverlag der TU Berlin.

24. Deif, A. M. (2011). A system model for green manufacturing. Journal of Cleaner Production, 19(14), 1553- 1559.

25. Mohiuddin, A. K. M., Saha, M. K., Hossian, M. S., \& Ferdoushi, A. (2014). Usefulness of banana (Musa paradisiaca) wastes in manufacturing of bio-products: a review. The Agriculturists, 12(1), 148-158.

26. Ceptureanu, E., Ceptureanu, S., Bologa, R., \& Bologa, R. (2018). Impact of Competitive Capabilities on Sustainable Manufacturing Applications in Romanian SMEs from the Textile Industry. Sustainability, 10(4), 942.

27. Pathak P, Singh MP (2017) Sustainable Manufacturing Concepts: A Literature Review. International Journal of Engineering Technologies and Management Research 4:1-13. https://doi.org/10.5281/zenodo.833990

28. Moldavska, A., \& Welo, T. (2017). The concept of sustainable manufacturing and its definitions: A content analysis based literature review. Journal of Cleaner Production, 166, 744-755.

29. Alayón, C. (2016). Exploring sustainable manufacturing principles and practices (Doctoral dissertation, Jönköping University, School of Engineering).

30. Rosen, M. A., \& Kishawy, H. A. (2012). Sustainable manufacturing and design: Concepts, practices and needs. Sustainability, 4(2), 154-174.

31. Barzegar, M., Ehtesham Rasi, R., \& Niknamfar, A. H. (2018). Analyzing the Drivers of Green Manufacturing Using an Analytic Network Process Method: A Case Study. International Journal of Research in Industrial Engineering, 7(1), 61-83.

32. Taghavi, N. (2015). Sustainable Manufacturing Strategy: Identifying Gaps in Theory and Practice (Doctoral dissertation, Chalmers University of Technology).

33. Nukmal, N., Umar, S., Amanda, S. P., \& Kanedi, M. (2018). Effect of styrofoam waste feeds on the growth, development and fecundity of mealworms (Tenebrio molitor). J Biol. Sci, 18, 24-28.

34. Organdi, Iwuozor Kingsley. 2018. Removal of Heavy Metals from Their Solution Using Polystyrene Adsorbent (Foil Take-Away Disposable Plates). International Journal of Environmental Chemistry. (2018); 2(2): 29-38.

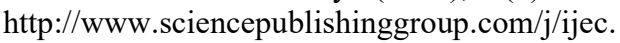
doi: 10.11648/j.ijec.20180202.11. ISSN: 26401452 (Print); ISSN: 2640-1460 (Online). 